\title{
Studia
}

SYNCHRONICZNE I DIACHRONICZNE ASPEKTY BADAŃ POLSZCZYZNY

www.wnus.edu.pl/sj | DOI: 10.18276/sj.2018.17-07 | 119-132

\section{Paulina Grabowska}

Uniwersytet Szczeciński, Wydział Filologiczny

\section{„Długie ogony kobiecych sukien” - językowe wyznaczniki opisu wizytowych sukien kobiecych w Kronikach tygodniowych Bolesława Prusa}

\author{
Słowa kluczowe \\ styl, Bolesław Prus, Kroniki tygodniowe \\ Keywords \\ style, Bolesław Prus, Kroniki tygodniowe ['Weekly Chronicles']
}

\section{Uwagi wstępne}

Bolesława Prusa uznaje się za jednego z najwybitniejszych polskich felietonistów XIX i początku XX wieku, jednak jego publicystyczna twórczość do dziś pozostaje przebadana jedynie w niewielkim stopniu. Pisarz tworzył Kroniki tygodniowe przez prawie 40 lat, począwszy od roku 1874 aż po $1912^{1}$. Dokumentował w nich przede wszystkim życie codzienne Warszawy - problemy społeczne, wydarzenia kulturalne i towarzyskie, nowinki techniczne itp. Jego bystrej obserwacji nie umknęła również kwestia ubioru, a szczególnie niepraktyczności kobiecej mody, która panowała w latach siedemdziesiątych XIX wieku.

\footnotetext{
${ }^{1}$ Zygmut Szweykowski, Wstęp do Kroniki, Bolesław Prus, t. I, cz. 1 (Warszawa: Państwowy Instytut Wydawniczy, 1956), 6.
} 
Celem niniejszego artykułu jest ukazanie językowych technik opisu noszenia przez zamożne kobiety sukien z trenem w miejscach publicznych Warszawy. Tekst jest również przyczynkiem do spojrzenia na sprawę mody damskiej w drugiej połowie XIX wieku, co wpisuje się w szerszy temat mojej rozprawy doktorskiej na temat językowo-kulturowego obrazu emancypacji kobiet w Polsce XIX wieku na przykładzie Kronik tygodniowych.

Przed przystąpieniem do analizy językowej nakreślony zostanie kontekst społeczno-historyczny wraz z kwestią mody panującej wśród pań w latach 70. XIX wieku, co jest niezbędne do prawidłowego zrozumienia obserwacji Prusa poczynionych we współczesnej mu Warszawie. By oddać stosunek felietonisty do badanego problemu, analizę językową rozpocznie określenie wieloznaczności rzeczownika ogon w polszczyźnie ogólnej tamtego okresu aż po znaczenie kontekstowe w Kronikach tygodniowych. Materiał do analizy (16 cytacji o zróżnicowanej długości) został wyekscerpowany z trzech pierwszych tomów Kronik Bolesława Prusa w opracowaniu wybitnego badacza jego twórczości, Zygmunta Szweykowskiego ${ }^{2}$. Felietony ujęte w wymienionych tomach powstały w latach $1874-1878$ i pochodzą z trzech różnych czasopism: z tygodnika satyrycznego „Kolce” (wyd. 18711898) oraz z dzienników: „Gazeta Polska” (wyd. 1826-1907 w Warszawie) i „Kurier Warszawski” (wyd. 1821-1939 w Warszawie).

W późniejszych felietonach można dostrzec zmianę zainteresowań - problem zaciekle krytykowanych kobiecych ogonów przestał wzbudzać emocje felietonisty i nie powrócił już w jego kolejnych tekstach, stąd zawężenie materiału badawczego do wspomnianego wyżej okresu.

\section{Osadzenie w kontekście historyczno-społecznym Warszawy lat siedemdziesiątych XIX wieku}

Bolesław Prus jako kronikarz nieodmiennie wykazywał się doskonałą spostrzegawczością i talentem do pomysłowego i dowcipnego charakteryzowania codziennych zjawisk w sposób oryginalny. Z perspektywy współczesnej trudno jest docenić niezwykły kunszt językowy felietonisty bez zagłębienia się w realia epoki, w jakiej przyszło mu żyć i tworzyć. Ze względu na charakter omawianego zagadnienia, uwaga skupiona zostanie na aspektach związanych z kobiecą modą oraz zwyczajem spędzania czasu w Ogrodzie Saskim przez zamożniejszych warszawiaków w latach siedemdziesiątych XIX wieku. Ogród ów cieszył się sławą Letniego Salonu, w którym od maja do września koncentrowało się życie towarzyskie stolicy $^{3}$. Henryk Sienkiewicz pisał o nim:

\footnotetext{
${ }^{2}$ Bolesław Prus, Kroniki, oprac. Zygmut Szweykowski, t. 1-3 (Warszawa: Państwowy Instytut Wydawniczy 1954-1956).

${ }^{3}$ Marta Wiśniewska, „Letnie salony Warszawy, czyli o modzie spacerowej warszawiaków w 2. połowie XIX wieku", Saeculum Christianum XXI (2014): 213.
} 


\begin{abstract}
Powioda was do Saskiego Ogrodu, pomiędzy tłumy, w ów modny chaos kurzu, sukien kobiecych, rzekomo paryskiego żargonu, tiurniur, parasolek, binokli, papierosowego dymu, nóżek niewieścich i rękawiczek - na koniec kobiet i mężczyzn. To wszystko, widzisz, nasza rozrywka, a zarazem, jeżeli chcesz, to nasza wystawa, wielki „magasin de modes" - wystawa ubrań, domowych zasobów pieniężnych i na koniec konkurs na wdzięki. Oto po ławkach siedzi złota młodzież, biegli sędziowie, a włożywszy na nos binokle, poważni, przejęci wielkością zadania, studiują starannie piękności ${ }^{4}$.
\end{abstract}

Ogród Saski był ówcześnie ulubionym miejscem spacerów elit warszawskich, lecz - co znamienne - głównym celem wielmożów nie była kontemplacja przyrody czy spędzenie czasu w gronie najbliższych, lecz korzystna autoprezentacja w pięknym otoczeniu i wywarcie możliwie jak najlepszego wrażenia na innych. Jak zauważa Ewa Paczoska, ,[...] do Ogrodu Saskiego nie chodzą marzyciele ani ludzie pytający o sens swojego życia; to raczej przestrzeń działania tych, którzy świetnie czują się we własnej skórze"־5. Próżność arystokracji, a szczególnie zniewolonych przez nakazy mody dam, wedle spostrzeżeń Prusa doprowadziła park do opłakanego stanu: [...] panie [...] chca zamienić ogród na salę balowa, a $w$ istocie zamieniają na coś środkującego między stodoła i rajtszulą ${ }^{6}$.

Przyczyną ostrej krytyki autora felietonów stał się zatem obszerny tren sukni, który stanowił ówcześnie niezbędny element stroju, świadczący o statusie społecznym jego posiadaczki. Jak pisze Maria Gutkowska-Rychlewska, ,[...] toalety takie przypominały pracowicie ułożone i podpięte przez mistrzów tapicerskich [...] portiery z ciężkich aksamitów i atłasów, zawieszane nad oknami i drzwiami mieszkań i salonów"7. Badaczka zauważa również, że ,[...] pomimo walorów estetycznych nowej mody ujemną jej stroną było niedostosowanie stroju do potrzeb życia codziennego" ". Długi tren niewątpliwie krępował swobodę ruchów kobiety, a to nie jedyna jego wada, jak przekonamy się z lektury Kronik tygodniowych.

\title{
Analiza językowa
}

\section{Wieloznaczność rzeczownika ogon w polszczyźnie drugiej połowy XIX wieku}

W wyekscerpowanym materiale Bolesław Prus konsekwentnie nazywa tren sukni ogonem, nie posiłkując się żadnym synonimem - czy to w znaczeniu literalnym, czy metaforycznym.

\footnotetext{
${ }^{4}$ Za: Marian Drozdowski, Andrzej Zahorski, Historia Warszawy (Warszawa: Jeden Świat 2004), 210.

${ }^{5}$ Ewa Paczoska, ,Lalka”, czyli rozpad świata (Białystok: „Trans Humana”- Wydawnictwo Uniwersyteckie, 1995), 37.

${ }^{6}$ Bolesław Prus, „Kurier Warszawski” 90, 26.04.1875, w: Kroniki, t. 2, 33-34.

${ }^{7}$ Maria Gutkowska-Rychlewska, Historia ubiorów (Wrocław-Warszawa-Kraków: Zakład Narodowy im. Ossolińskich 1968), 793-794.

8 Tamże, 794.
} 
Nacechowanie tego określenia jest niewątpliwie ujemne, choć zależnie od kontekstu może być mniej lub bardziej ironiczne, szydercze lub komiczne, co zostanie zobrazowane na przykładach.

Z porównania znaczeń wyrazu ogon w słownikach: Lindego ${ }^{9}$, warszawskim ${ }^{10}$ i słowniku pod redakcją Witolda Doroszewskiego ${ }^{11}$ wynika, że użycie przenośnego znaczenia tego rzeczownika przez Prusa nie było innowacyjne, ale podyktowane tradycją językową, utrwaloną już wcześniej w polskiej literaturze. Metafora ogony sukien była oparta na podobieństwie skojarzeń i występowała w polszczyźnie ogólnej aż do rewolucji obyczajowej, w której wyniku powłóczyste treny zostały zarezerwowane niemal wyłącznie dla sukien zakładanych na uroczyste gale i straciły zastosowanie w codziennej, potocznej odmianie języka.

Samuel Bogumił Linde wspomina o ogonie u szaty białogłowskiej (Linde III, 519), ilustrując to użycie licznymi przykładami, m.in. z utworów Wacława Potockiego i Jana Kochanowskiego. Redaktorzy wydanego sto lat później Słownika warszawskiego objaśniają wyraz z kwalifikatorem przen. jako: 'przedłużenie sukni w tyle, ścielące się po ziemi; tren' (SW III, 713). Z kolei w słowniku pod redakcją Witolda Doroszewskiego metaforyczne znaczenie wyrazu ogon zostało zarejestrowane jako 'przedłużenie tyłu spódnicy, wlokące się po ziemi, stosowane dawniej w strojnych sukniach; tren’ (SJPD V, 874).

Dostrzeżenie podobieństwa trenu sukni do ogona nie było wytworem fantazji Prusa, lecz powszechnie znanym w ówczesnej polszczyźnie zjawiskiem. Felietoniście zaś trudno odmówić niezwykłej umiejętności operowania skalą emocji służących do opisywania zjawiska. Aby lepiej uwidocznić sposób prezentowania badanego problemu, zebrane cytacje podzielono na mniejsze fragmenty ze względu na zawarty w nich rodzaj odczuć: ironię, szyderstwo oraz emocje neutralne i pozytywne.

\section{Ironia}

W materiale badawczym dominuje odcień ironiczny bądź kpiarski. Ten środek wyrazu upodobał sobie Prus do opisywania kobiecego ogona, nacechowując go wprawdzie ujemnie, z pewną złośliwością, ale w sposób tak humorystyczny i przenikliwy, że wywołuje raczej rozbawienie niż urazę. Autor chętnie odwołuje się do środków stylistycznych, które wzbogacają opisy o walor literacki, co doskonale obrazuje poniższy przykład:

\footnotetext{
${ }^{9}$ Samuel Bogumił Linde, Stownik języka polskiego, t. III (Warszawa: Państwowy Instytut Wydawniczy, 1951) (dalej: Linde).

${ }^{10}$ Stownik języka polskiego, red. Jan Karłowicz, Adam Antoni Kryński, Władysław Niedźwiedzki, t. III (Warszawa: Państwowy Instytut Wydawniczy, 1952) (dalej: SW).

${ }^{11}$ Stownik języka polskiego, red. Witold Doroszewski, t. V (Warszawa: Państwowe Wydawnictwo Naukowe, 1963) (dalej: SJPD).
} 
[...] wybiła godzina, żem i ja naprawdę miat już wejść do salonu i osobiście narazić się na pokusy, którym nawet pustelnicy ulegali. [...] Kto mi zdjąt palto w przedpokoju i jakim sposobem wszedłem na salon, nie wiem. To wiem, że ustyszałem śmiechy i rozmowy, żem ujrzat w oknach tyle kwiatów jak w ogrodzie, a w salonie mnóstwo pań. Każda zajmowała miejsce dla trzech osób, a na posadzce drzemały zdradzieckie ogony ich sukien, na podobieństwo owego węża z raju, który namyślat się: w jaki by tė sposób zgubić pierwszego człowieka? „Kurier Warszawski”, nr 59, 16.03 .1877 (t. 3, s. 65-66) ${ }^{12}$.

Ten krótki cytat zawiera wiele różnych tropów - w tym porównania (tyle kwiatów jak w ogrodzie, ogony na podobieństwo węża z raju), animizacje (na posadzce drzemały ogony sukien), epitety metaforyczne (zdradzieckie ogony), pytania retoryczne (w jaki by té̇ sposób zgubić pierwszego człowieka?). Cały fragment jest nie tylko przesycony ironią, ale również hiperbolizacją niezwykłej pokusy, jaką wzbudzają wśród mężczyzn treny sukien. Jest to wreszcie nawiązanie do motywu biblijnego kuszenia Ewy przez węża.

Kolejny przykład zawiera inne środki wyrażania:

„,Kobieto! puchu marny, ty wietrzna istoto! nie wiem, czego ci zazdroszcza anieli, bo nosisz ogon straszniejszy niżeli sam szatan...” Czy przesadzam?... Ogon twój kosztujacy od kilku złotych do kilkunastu rubli, ma przynajmniej dwa łokcie długości i tyleż szerokości - całemu zaś światu wiadomo, że szatani posiadaja albo krótkie ogony kozie, albo wąskie krowie; a nawet ten, którego ja widziałem, cieszyt się zaledwie cielęcym ogonina i jeszcze w garści go nieboraczek dźwigat!... „Kolce”, nr 24, 13.06.1874 (t. 1, cz. 1, s. 104-105).

Parafraza apostrofy Kobieto! puchu marny...! z monologu Gustawa z Dziadów Mickiewicza przyciąga uwagę czytelnika. Mimo pozornie zachowanego stylu podniosłego z wykorzystaniem archaizmów leksykalnych, Prus naigrywa się z fantastycznego, odrealnionego problemu szatańskich ogonów, które odnosi porównawczo do trenu sukni kobiecej. Wskazuje ponadto na koszt takiej sukni, który wpływał na znaczące obciążenie budżetu domowego.

Oprócz przekształceń semantycznych i znanych odniesień kulturowych, autor czerpie z synkretyczności gatunkowej, jaką zapewnia forma felietonu, wprowadzając w obręb tekstu fikcyjną anegdotę z zaskakującą i dowcipną puentą:

Pewny Müller z Monachium podat projekt, aby dla zwiększenia funduszów państwowych ustanowiono podatek ,od ogonów”. Zrobil się gwatt, Niemcy bowiem twierdzili, ze z chwila wprowadzenia podatku trzeba będzie oszpecić wszelkie zwierzęta domowe albo wyrzec się mleka, mięsa i sera. Obywatelski ten wniosek przyprawit jego twórce

\footnotetext{
${ }^{12} \mathrm{~W}$ nawiasach okrągłych umieszczonych na końcu cytatów wskazuje się lokalizację w tomie Kronik i stronę, z której pochodzi cytat.
} 
o ciężkie kłopoty. Biedny Müller bowiem od tej pory nic już robić nie mógt, tylko albo wyrzucat za drzwi, albo też grzecznie tłomaczyt swoim przeciwnikom, że nowym podatkiem nie chciał bynajmniej okładać ogonów krowich, cielęcych, końskich, lecz tylko ogony sukien damskich. „Kurier Warszawski”, nr 98 i 99, 3-4.05.1876 (t. 2, s. 363).

Trudno nie dostrzec absurdalności sytuacji, w której dwuznaczność wyrazu ogon stała się powodem tak poważnego nieporozumienia. Ironia w stosunku do formy sukien kobiecych w powyższym fragmencie jest subtelnie wyrażona w puencie, która wyjaśnia powód nieporozumienia.

W innej kronice Prus opisuje fikcyjne wydarzenia związane z podjętą przez mężczyzn próbą walki z powłóczystością trenów:

Już lekkomyślni wiedeńczycy zawiazali towarzystwo przeciw waszym ogonom: a chcecie wiedzieć jakie? Oto takie, którego członkowie chodza w butach ostro podkutych $i$ bez miłosierdzia dra nimi każdy zbyt wystajacy szczegót niewieściej tualety. Może myślicie, że będziemy ich naśladować? Zapewne!... Po to chyba, abyśmy nic nie zrobili $i$ więcej kosztów ponieśli. Lecz nie tryumfuj jeszcze, o płci nadobna! I w Warszawie zawiazuje się towarzystwo przeciw wybrykom twoim - lecz członkowie jego, zamiast pracować na własna niedole, postanowili chwycić się praktyczniejszego środka. Oto: nie będa chodzić tam, gdzie wy spacerujecie. Czy pani dobrodziejka wyobrażasz sobie, jak będzie wyglądat Saski i Botaniczny Ogród, w którym reprezentanci ptci brzydkiej zredukują się do kilku mocno nadwyrężonych osobników sprzedajacych wodę studzienną? I na co wówczas przydadza się aleje, w których nikt podziwiać nie będzie waszych naturalnych i prawie naturalnych wdzięków? Na co przyda się ów ponętny szelest waszych sukien, który nikogo nie zwabi?... „Kolce”, nr 24, 13.06.1874 (t. 1, cz. 1, s. 104-105).

We wszystkich trzech cytatach na pierwszy plan wysuwa się dialogowość tekstu, wyrażona $\mathrm{w}$ formie apostrof do kobiet, które są adresatkami wypowiedzi nadawcy, a następnie wykrzyknienia oraz pytania retoryczne. Po raz kolejny puenta w formie pytanie retorycznego jest głównym nośnikiem ironii, zaskakując czytelnika propozycją nietypowego rozwiązania problemu. Prus objawia swoją pomysłowość nie tylko w sferze językowej, ale także pragmatycznej, z humorem podpowiadając mężczyznom, jak uporać się z uciążliwą modą.

Innym przykładem ironicznego spojrzenia autora na problem ogonów jest porównanie kobiet do żółwi. Poniższy cytat w tekście kroniki jest poprzedzony wzmianką o pojawieniu się w Warszawie ogromnego przedstawiciela żółwiego gatunku i humorystycznym opisem jego cech:

Damy i panowie! czy sadzicie, że na tym tylko ogranicza się moja znajomość rodu żótwiego? Otóż nie! i na dowód tego zacytuję wam, że pteć piękna tej rasy nosi ogony podobnie jak doskonalsza połowa rodzaju ludzkiego, lecz że nie używa koków, nie 
chodzi z mężami pod rękę, spazmy zna tylko ze styszenia, a o prawach kobiet nie ma nawet idei, nie czytując dzieł odpowiednich... „Kurier Warszawski”, nr 240 i 241, 2930.10 .1875 (t. 2, s. 158).

Z przymrużeniem oka felietonista porównuje wygląd kobiet w sukniach $\mathrm{z}$ trenami do ogromnych żółwi, z którymi łączy je posiadanie ogona. W kolejnych kronikach Prus wykorzystuje skojarzenia animistyczne, postrzegając tren jako część ciała podlegającą ewolucji, co wynika z jego zainteresowań teorią Darwina:

[Warszawę nawiedziło powietrze wiosenne z odcieniem letnim] Potwierdzaja to [...] ogony damskich sukien, które na pociechę nie przebierajacych $w$ środkach darwinistów rosna proporcjonalnie do ilości kurzu w Saskim Ogrodzie. „Gazeta Polska”, nr 117, 29.05 .1874 (t. 1, cz. 1, s. 180-181).

Krótkie sukienki, nad które we właściwym czasie nie było nic piękniejszego, zdarwinizowały się i przekształcity $w$ fałdziste i ogoniaste szaty. [...] Wszędzie moda i moda. „Kurier Warszawski”, nr 140 i 141, 30.06-1.07.1875 (t. 2, s. 102).

Kolejny przykład to fragment kroniki opisującej ceremonię puszczania wianków, która odbywała się z okazji przesilenia letniego i przyciągała rzesze warszawiaków:

Kto jesteś tyle szczęśliwym, że posiadasz już druga połowę twej istoty - nie zapomnij przede wszystkim ubrać ja w suknię od wielkiego dzwonu, z dlugim ogonem. Tym sposobem osiagniecie dwa rezultaty: pierwszy indywidualno-ekonomiczny, który zamanifestuje się oberwaniem ogona u sukni, drugi zaś społeczno-higieniczny, polegajacy na zwiększeniu ogólnej ilości kurzu tak na ulicach miasta, jak i na placu zabawy. „Kolce”, nr 26, 27.06.1874 (t. 1, cz. 1, s. 115-116).

Tym razem autor ironicznie, wręcz kpiarsko, zwraca się do mężczyzn w formie dwu rozwiniętych wypowiedzeń złożonych, że nie oponują przeciwko niepraktycznym strojom wyjściowym swoich małżonek. Korzystając z dowcipnych złożeń przymiotnikowych (indywidualno-ekonomiczny, społeczno-higieniczny), przedstawia skutki próżnego podążania za modą, co wiąże się z utratą pieniędzy wydanych na powłóczystą suknię oraz niepotrzebnym wzniecaniem kłębów kurzu przez tren.

Autor Kronik pozostaje wierny przede wszystkim dobru społecznemu i szuka w dyskursie z adwersarzem rozwiązań, które pomogą zniwelować niedoskonałości dostrzegane przez niego w mieście. Wszechobecny kurz, szczególnie w Ogrodzie Saskim, jest jedną z takich właśnie niedoskonałości, stąd liczne próby dowcipnego skierowania uwagi na ten problem. W listopadzie, kiedy pogoda przestała sprzyjać zarówno spacerom, jak i długim trenom, Prus z ulgą zauważa: 
Ogony u sukien znikty, a wraz z nimi kurz w Saskim Ogrodzie. „Kurier Warszawski”, nr 260 i 262, 23 i 25.11 .1875 (t. 2, s. 197).

Czy rzeczywiście to kobieca moda powodowała zanieczyszczenie powietrza, czy raczej niesprzątanie parkowych alejek i sucha pogoda? Felietonista niewątpliwie zdawał sobie sprawę z przesady swojego stanowiska, stąd autoironia w jednej z kronik:

A może mniemasz pan, że po raz dziesiąty w życiu z wysokości publicznej kazalnicy przemawiać będę do ogonów sukien damskich, aby mniej robity kurzawy, lub do samychże dam, aby ogony skrócity?... Znowu nie! Praktyka bowiem dziennikarska nauczyla mnie, że odwolywanie się do względności ogonów wydaje takie same rezultaty jak na przykład poleganie na zdrowym rozsądku „,Kuriera Codziennego”. „Kurier Warszawski”, nr 123, 9.06.1875 (t. 2, s. 76).

\section{Szyderstwo}

W pierwszej części przytoczono cytacje, w których Bolesław Prus wprawdzie krytykuje i naśmiewa się z długich trenów, jednak czyni to w sposób humorystyczny, okraszając złośliwości dużą dozą komizmu. Kolejne odczucie, które ujawnia się w badanych rozważaniach, to szyderstwo o silnie ujemnym nacechowaniu. Tym razem felietonista nie przebiera w środkach, by wydrwić kobiecą próżność w sposób znacznie ostrzejszy, co obrazuje poniższy przykład:

Na zakończenie pozwólcie mi, szanowni czytelnicy, uronić kilka łez nad opłakana dola Saskiego Ogrodu, którym rokrocznie o tej porze zajmuja się wszystkie pisma, a zawsze z jednakowym skutkiem. Otóż nie owijajac kwestii w bawetnę i nie filtrując wyrazów, zaznaczamy z góry, że piękne to z pozoru ustronie byłoby największym skarbem dla miasta, gdyby nad nim nie ciązyly dwie straszne plagi, jakimi sa kobiety i dzieci. Dzięki bowiem ogonom pierwszych i przez nikogo nie krepowanemu niechlujstwu drugich Saski Ogród, po bliższym rozpatrzeniu się w nim, wyglada tak, jak w czasie jarmarku rynek żydowskiego miasteczka. Nie ma chyba na całym świecie ogrodu, o którym by powiedzieć można, że wtedy jest najprzyjemniejszy i najbardziej kwalifikuje się do przechadzki, kiedy deszcz pada; z naszym przecież tak jest, niestety! Niech bowiem tylko stońce zaświeci i ulice podeschna, wnet każda aleja zamienia się w stodołę, w której młóca zboże, a każdy klomb w oborę, jeżeli nie coś gorszego jeszcze. „Kolce”, nr 26, 27.06.1874 (t. 1, cz. 1, s. 115-116).

Szydercza i okrutna ocena ubioru kobiety jest podyktowana chęcią obrony dobra wspólnego - zaniedbanego Ogrodu Saskiego. Bolesław Prus użył tu zdań złożonych, zarówno współrzędnie, jak i podrzędnie, by wyłożyć szczegółowo przyczyny zła. Wykorzystuje 
ponadto porównanie, by wzmocnić ujemną ekspresję, np.: Saski Ogród [...] wygląda tak, jak w czasie jarmarku rynek żydowskiego miasteczka. W dalszej części tej samej kroniki grzmi:

Najściślejszy i najsurowszy dozór policyjny nie zastapi poszanowania dla praw osób trzecich $i$ wstrętu do pewnych oburzających nieporządków - jak najgwattowniejsza filipika dziennikarska nie rozbudzi uczuć, które nadać powinno wychowanie. Cudzoziemcy zarzucaja nam niechlujstwo, i stusznie; Saski Ogród może postużyć za jeden więcej dowód ich opinii, która w tym, co się Ogrodu dotyczy, zawdzięczamy wam, szanowne panie, waszemu niedbalstwu o dzieci i bezmyślnemu hołdowaniu kaprysom niedorzecznej mody. „Kolce”, nr 26, 27.06 .1874 (t. 1, cz. 1, s. 115-116).

Powyższe fragmenty świetnie ilustrują emocje związane z dbałością o kondycję ulubionego warszawskiego parku, którą Prus zdecydowanie przedkładał nad potrzebę korzystnego prezentowania się kobiet $\mathrm{w}$ trakcie spaceru. Uczynił z kobiet główne winowajczynie opisywanej sytuacji, choć zanieczyszczenie powietrza wynikało z wielu czynników, a długie treny mogły je co najwyżej nieco zwiększać. W tym celu wykorzystał wyliczenia, apostrofę i inne techniki językowego obrazowania. Jego krytyka jest wyolbrzymiona, zajadła i nie do końca sprawiedliwa, jednak subiektywność jest prawem felietonisty, z którego skwapliwie autor korzystał.

Przesada i uszczypliwość w stosunku do kobiet świetnie uwidacznia się również w poniższym fragmencie:

Odpowiedz mi, o kobieto! na co ci ten szmat tkanin, który mimo cała prostote form spetnia od razu funkcja miotty, szczotki, choragwi, stomianki, żagla i czterdziestu tysięcy innych nie podobnych do siebie przedmiotów? Przydaż ci się on do plywania czy do latania, a może do skakania, odpędzania dokuczliwych owadów lub czepiania się na gatęziach? Czy też tylko chcesz nim szeleścić po woskowanej, marmurowej lub nawet nie dość starannie umytej posadzce, jak grzechotnik przesuwajacy się między gęstymi splotami podzwrotnikowych lasów?... „Kolce”, nr 24, 13.06 .1874 (t. 1, cz. 1, s. 104-105).

Potencjalne szkody wynikające $\mathrm{z}$ istnienia sukni z trenem zawarte są w długich, zjadliwych wyliczeniach - suknia spełnia funkcję: miotly, szczotki, choragwi, słomianki, żagla i czterdziestu tysięcy innych niepodobnych do siebie przedmiotów, ma zastosowanie do: ptywania, latania, skakania, odpędzania dokuczliwych owadów, czepiania się na gałęziach. Ponadto Prus posługuje się szyderczym porównaniem wystrojonej damy do wzbudzającego grozę węża, co potęguje jeszcze efekt wyolbrzymienia opisywanego zjawiska. Perswazyjność tekstu podkreślają: apostrofa i rozbudowane składniowo pytania retoryczne.

Zaciekła obrona Ogrodu Saskiego staje się usprawiedliwieniem okrutnej i złośliwej krytyki kobiet, choć panujące ówcześnie konwenanse oraz typowe dla wyższych sfer wychowanie nie pozostawiało im wyboru, lecz tylko stosowanie się do reguł narzucanych przez modę. Dla Prusa istotniejsze od panujących obyczajów jest zadbanie o miejską przestrzeń, 
a wyraz temu dążeniu daje w poniższym fikcyjnym liście od czytelnika, wplecionym w treść kroniki:

[list od czytelnika] Nr 3: Jestem sobie, panie dobrodzieju, uczciwym i spokojnym obywatelem i nie lubię wsadzać nosa do cudzego prosa, ale te babskie wybryki stanęty mi już kościa w gardle i dlatego umyślitem raz, a dobrze wystapić. Z tego powodu umyślitem sobie niniejszym zaproponować nastęujaca propozycja, aby dla uratowania zdrowia i życia ludzkiego tudzież dla niezanieczyszczania Saskiego Ogrodu rozdane byly stróżom przy tymże ogrodzie stojacym, wielkie nożyce celem ucinania ogonów u sukien kobiecych, wedtug miary, jaka przy niniejszym załaczam. „Gazeta Polska”, nr 117, 29.05.1874 (t. 1, cz. 1, s. 180-181).

Wprowadzenie drugiego nadawcy pozwoliło zastosować stylizację na socjolekt szlachecki z elementami archaicznymi (np. apostrofa panie dobrodzieju), by bardziej stanowczo wyrazić dezaprobatę wobec kobiecej mody. W żadnym innym z wybranych fragmentów Kronik nie występuje wyrażenie babskie wybryki, choć w trakcie lektury trudno nie odnieść wrażenia, że autor chętnie by je powtarzał. Epokowe obyczaje, delikatność i szacunek wobec dam nie pozwalały na tak dosadne wyrażenia, dlatego przypisał je fikcyjnemu nadawcy listu wraz z drastyczną propozycją rozwiązania problemu trenów.

\section{Nacechowanie pozytywne i neutralne}

Kobiece treny nie zawsze stanowiły obiekt ostrej krytyki, złośliwości czy kpiny Bolesława Prusa. W materiale badawczym znalazły się również fragmenty, w których emocje autora są bardziej wyważone i oscylują między neutralną obserwacją a chęcią życzliwego umoralnienia czy wręcz odrobiną współczucia dla zniewolonych kaprysami mody pań. Felietonista prezentuje różne punkty widzenia, co uwidacznia się w odpowiedzi na fikcyjny list od czytelnika przytoczony wcześniej:

Stuszność wymaga, aby w sprawie tak drażliwej wszyscy uczciwi i spokojni obywatele głos zabierali, redakcja jednak dla wystuchania ich nie ma czasu, a przy tym nie chce sobie narażać ptci pięknej. Dodać w tym miejscu wypada, że sądząc z miar przez panów nadesłanych, już nie tylko istnienie ogonów, ale nawet sukien damskich bytoby zakwestionowane. Że zaś nie przypuszczamy, abyście panowie mieli zamiar cofnać ludzkość do epoki pierwszych naszych rodziców, postanowiliśmy więc oznaczenie dtugości mających się poucinać ogonów zostawić damom, w nadziei, że takowe zechca uwzględnić uprzejme i stuszne skądinąd propozycje obu panów. „Kurier Warszawski”, nr 111 i 112, 25-26.05.1875 (t. 2, s. 60-61).

Komunikacja werbalna z czytelnikiem wskazuje, że autor wystąpił w roli obrońcy kobiecej swobody i niezależności w zakresie podejmowania decyzji związanych z ubiorem. 
W zdaniach wielokrotnie złożonych podaje argumenty wyjaśniające, zaś za pomocą perswazji zwraca się do kobiet w sposób uprzejmy, a nawet uniżony, właściwy XIX-wiecznemu dżentelmenowi.

W nielicznych fragmentach można zauważyć uznanie dla kobiecego wdzięku i stwierdzenie, że wyjściowe suknie zachwycają mężczyzn. Suknia z trenem jest atrybutem kobiety i symbolem jej powabu, co ilustrują następujące przykłady:

Wypiłem [szklankę hiszpańskiego wina] $i$ (dziwna rzecz!) o tobiem naprzód pomyślał, o płci piękna! Że zaś, ile razy duch mój skierowuje się ku tej stronie, tyle razy budzi się drzemiaca muza, siadam więc i piszę pod twym wezwaniem, o dtugowtosa i dtugoogonowa połowo rodu ludzkiego, tudzież pod wpływem bursztynowego soku jagód ciepłej Iberii, której niebaczni synowie zamiast patrzeć w ciemne oczy i raczyć się złocistym likworem, strzelają sobie w tby! „Kolce”, nr 28, 11.07 .1874 (t. 1, cz. 1, s. 122).

Nie znam mężczyzny, który by wnet na widok ogona sukni kobiecej nie dostawat dreszczów. „Kurier Warszawski”, nr 87, 21.04 .1877 (t. 3, s. 101).

Szczególnie interesujący jest pierwszy cytat. Tekst w formie rozwiniętych wypowiedzeń złożonych zawiera archaizmy (np. likwor), apostrofy (o płci piękna, o dlugowłosa i dtugoogonowa połowo rodu ludzkiego) i poetyckie metafory (np. bursztynowy sok jagód ciepłej Iberii, budzi się drzemiaca muza). Zwrot potoczny strzelać sobie $w$ teb oraz żartobliwa metafora w postaci wyrażenia dtugoogonowa połowa rodu ludzkiego przełamują patetyczność cytowanego fragmentu i nadają mu walor humorystyczny.

W innej kronice Prus zwraca się do współczesnych mu kobiet z lekką ironią, ale i dużą dozą empatii:

O, piękne i nadobne panie nasze!... także to zmarniat ród waszych rycerzy, że już nie tylko miecza, ale i kija żaden z nich w waszej obronie użyć nie potrafi? Na ulicach gbury bezkarnie potraccaja was i zaczepiaja, w salonach wędza was dymem papierosów, na pocztach, statkach i kolejach najgorsze pozostawiaja wam miejsca... A wy?... ach! wy tymczasem nosicie suknie z dtugimi ogonami i szeroko o emancypacji rozprawiacie. Macież emancypacją, macie porównanie ptci - korzystajcież z niej teraz, biedaczki! „Kolce”, nr 31, 1.08 .1874 (t. 1, cz. 1, s. 139).

Felietonista dostrzega trudności, z jakimi borykają się kobiety oraz spadek należnego im szacunku. Za pomocą apostrofy: O, piękne i nadobne panie nasze! zwraca się uprzejmie do czytelniczek i zadaje retoryczne pytanie o postawę mężczyzn w formie ironii zawartej w metaforze ród rycerzy. Ekspresję opisu przykrości, na jakie narażone są damy, wzmacnia forma zdania wielokrotnie złożonego oraz zastosowanie potocyzmów nacechowanych ujemnie (gbury, wędzić kogoś dymem papierosów). Zwroty do kobiet zawierają wykrzyknienia 
(np. ach!) oraz określenia wartościujące pozytywnie (piękne i nadobne panie nasze), jak również współczująco (biedaczki).

\section{Podsumowanie}

1. Zarejestrowany przez Prusa w Kronikach zwyczaj noszenia sukni z trenem oraz tego konsekwencje stały się kanwą fascynujących, przebogatych językowo tekstów, które do dziś bawią czytelników dowcipnymi porównaniami, żartobliwymi anegdotami czy zaskakującymi puentami. Zagadnienie kobiecych ogonów powracało w felietonach przez kilka lat, wzbudzając różne emocje u autora - od skrajnie negatywnych, poprzez te nacechowane mniej ujemnie, aż po neutralne i pozytywne.

2. Zaprezentowane cytaty obrazują duże zróżnicowanie emocji i skojarzeń powiązanych z pojęciem kobiecego ogona w poszczególnych kronikach Prusa. Pisarz zastosował zjawisko z różnych perspektyw i ze zmiennym nastawieniem, wykorzystał wiele środków stylistycznych, takich jak apostrofy, porównania, metafory, pytania retoryczne czy wykrzyknienia, co świadczy o jego wrażliwości społecznej, spostrzegawczości, otwartości umysłu oraz wybitnym talencie felietonowym.

3. W wybranym materiale zdecydowanie dominowała ironia, która była dla Prusa ulubionym narzędziem krytyki panującej mody. Często występowało również szyderstwo wymierzone bezpośrednio w ulegające trendom kobiety, jednak pisarz potrafił obrać odmienny punkt widzenia i stanąć po stronie pań, a ogon uczynić symbolem ich piękna i uroku. Warto podkreślić, że nawet najbardziej okrutna kpina z babskich wybryków i płochości dam była podyktowana dbałością o dobro wspólne - przestrzeń publiczną, a przede wszystkim ukochany Ogród Saski. Autor występował w roli obrońcy miasta, a jego głównym celem było zwrócenie uwagi na problem zanieczyszczenia powietrza. Przypisywanie powłóczystym trenom winy za panujące $\mathrm{w}$ Warszawie warunki było znaczącym wyolbrzymieniem, które stawało się często pretekstem do wprowadzenia komizmu oraz zastosowania całej gamy środków językowych, np. apostrof (o piękne i nadobne panie nasze, o ptci piękna, Odpowiedz mi, o kobieto!), wykrzyknień (Otóż nie!, Ach!) i pytań retorycznych (Czy przesadzam?). Felietonista prowadził dialog z czytelnikami, komunikując istnienie problemu i stosując perswazję. Wyolbrzymiał konsekwencje noszenia trenów, aby uświadomić kobietom ich niepraktyczność i skłonić do rezygnacji ze spacerów w powłóczystych sukniach. Zastosowanie gatunku felietonu sprawiło, że umoralniający przekaz przybierał różne formy (np. list), a jednym z celów autora było rozbawienie i zaskoczenie odbiorcy oryginalnością porównań (np. kobiet w powłóczystych sukniach do żółwi), metafor (np. ogon jako pokusa) i wyliczeń (np. suknia spełnia funkcje: miotty, szczotki, choragwi, stomianki, żagla i czterdziestu tysięcy innych niepodobnych do siebie przedmiotów). 
Problem trenów zaprzątał Prusa przez trzy lata. Wreszcie zwyczaj ich noszenia zaczął powoli przemijać, co pisarz odnotował z właściwą sobie ironią i zakończył ostatecznie swoją krucjatę:

Rok 1878 [...] zacząt się w ogóle dość pomyślnie. [...] Śnieg leży na ulicach, właśnie jak powinien, księzyc ulega zmianom we właściwym czasie, a stroje dam na balach odznaczaja się gustownościa jak w latach poprzednich. Sa tylko nieco węższe niż zwykle, na co przecież nie skarża się znawcy ani dyletanci. „Kurier Warszawski”, nr 10, 12.01 .1878 (t. 3, s. 165).

\section{Bibliografia}

\section{Źródła}

Prus, Bolesław. Kroniki. T. I-III. Warszawa: Państwowy Instytut Wydawniczy, 1954-1956.

\section{Opracowania}

Drozdowski, Marian, Andrzej Zahorski. Historia Warszawy. Warszawa: Jeden Świat, 2004.

Gutkowska-Rychlewska, Maria. Historia ubiorów. Wrocław: Zakład Narodowy im. Ossolińskich - Wydawnictwo, 1968.

Paczoska, Ewa. „Lalka”, czyli rozpad świata. Białystok: Trans Humana, 1995.

Szweykowski, Zygmunt. Wstęp do Kroniki, Bolesław Prus. T. I, cz. 1. Warszawa: Państwowy Instytut Wydawniczy, 1956.

Wiśniewska, Marta. „Letnie salony Warszawy, czyli o modzie spacerowej warszawiaków w 2. połowie XIX wieku”. Saeculum Christianum XXI (2014): 211-222.

\section{Słowniki}

Doroszewski, Witold, red. Stownik języka polskiego. T. V. Warszawa: Państwowe Wydawnictwo Naukowe, 1963.

Linde, Samuel Bogumił. Stownik języka polskiego. Warszawa: Państwowy Instytut Wydawniczy, 1951.

Karłowicz, Jan, Adam Kryński, Władysław Niedźwiedzki, red. Słownik języka polskiego. Warszawa: Państwowy Instytut Wydawniczy, 1952.

„Długie ogony kobiecych sukien” - językowe wyznaczniki opisu wizytowych sukien kobiecych w Kronikach tygodniowych Bolesława Prusa

Streszczenie

W artykule poddano analizie sposób opisywania trenów damskich sukien wizytowych na podstawie 16 cytacji wyekscerpowanych z trzech pierwszych tomów Kronik Bolesława Prusa. Celem badań było określenie wyznaczników językowych opisu tzw. ogonów kobiecych oraz intencji, które skłaniały autora do wielokrotnego poruszania tego problemu w felietonach na przestrzeni lat 1874-1878. W tym okresie panujące zwyczaje obligowały damy do noszenia powłóczystych sukien, również $\mathrm{w}$ trakcie spacerów. Na podstawie słownika Lindego oraz 
słownika warszawskiego stwierdzono, że metaforyczne zastosowanie rzeczownika ogon w odniesieniu do trenu było znane w polszczyźnie XIX wieku. Wybrane cytaty podzielono ze względu na nacechowanie: ironiczne, szydercze oraz pozytywne i neutralne. Dominujące okazały się emocje negatywne, które uwidaczniają się w ostrej i często wyolbrzymionej krytyce. Bolesław Prus zastosował wiele środków językowych, by zobrazować absorbujący go problem: metafory, porównania, epitety, animizacje, wyliczenia, pytania retoryczne, apostrofy. Stwierdzono, że jego głównym celem jest uświadomienie niepraktyczności trenów i ich szkodliwego wpływu na warunki panujące w warszawskim Ogrodzie Saskim, gdzie wzmagały zanieczyszczenie powietrza. Korzystając z praw przysługujących felietoniście, Prus zobrazował problem w sposób humorystyczny, z zastosowaniem licznych środków stylistycznych, co zostało zaprezentowane na przykładach.

\section{'Long trains of women's dresses' - language indicators depicting women's formal dresses in Kroniki tygodniowe ['Weekly Chronicles'] by Bolesław Prus}

Sum mary

The article contains an analysis of the ways of describing women's formal dress trains on the basis of the sixteen quotations excerpted from the first three volumes of 'Weekly Chronicles' by Bolesław Prus. The purpose of the research is to determine the language description indicators of the so called 'women's trains' and to discover the reasons why the author so often mentioned them in his Chronicles in the years 1874-1878. At that time according to traditional customs ladies were obliged to wear sweeping dresses, even while strolling. Both the Polish Language Dictionary of S.B. Linde and the Warsaw dictionary state that the metaphorical usage of the noun ogon ['tail'] in the meaning of 'women's train' had been known in the Polish language of the $19^{\text {th }}$ century. The quotations are divided according to how they have been marked: ironically, sneeringly, positively or neutrally. Negative emotions have turned out to be the dominant ones and they are expressed in the form of harsh and exaggerated criticism. Bolesław Prus used many language means in order to portray the problem that he was absorbed by: metaphors, similes, epithets, animalisation, enumeration, rhetorical questions, and apostrophes. The writer wanted to highlight how impractical women's trains were and what negative impact they had on the conditions in the Warsaw Saxon Garden (Ogród Saski), where they contributed to the deterioration of air pollution. As a columnist Prus portrayed the problem in a humorous way using numerous stylistic means, which have been presented with examples.

Cytowanie

Grabowska, Paulina. „Długie ogony kobiecych sukien” - językowe wyznaczniki opisu wizytowych sukien kobiecych w Kronikach tygodniowych Bolesława Prusa". Studia Językoznawcze. Synchroniczne i diachroniczne aspekty badań polszczyzny 17 (2018): 119-132. DOI: 10.18276/sj.2018.17-07. 